\title{
Organic Rankine Cycle (ORC) System Applications for Solar Energy: Recent Technological Advances
}

\author{
T. M. I. Mahlia ${ }^{1}$, H. Syaheed ${ }^{2}$, A. E. Pg Abas ${ }^{3}$, F. Kusumo ${ }^{2,4, *}$, A. H. Shamsuddin ${ }^{2}$, \\ Hwai Chyuan Ong ${ }^{5}$ and M. R. Bilad ${ }^{6}$
}

1 School of Information, Systems and Modelling, Faculty of Engineering and Information Technology, University of Technology Sydney, Sydney, NSW 2007, Australia

2 Institute of Sustainable Energy, Universiti Tenaga Nasional, 43000 Kajang, Selangor, Malaysia

3 Faculty of Integrated Technologies, Universiti Brunei Darussalam, Jalan Tungku Link, Gadong BE1410, Brunei Darussalam

4 Department of Computer Science \& Information Technology, College of Computer Science \& Information Technology Universiti Tenaga Nasional, 43000 Kajang, Selangor, Malaysia

5 Department of Mechanical Engineering, Faculty of Engineering, University of Malaya, 50603 Kuala Lumpur, Malaysia

6 Chemical Engineering Department, Universiti Teknologi PETRONAS, Seri Iskandar, 32610 Perak, Malaysia

* Correspondence: fitrantokusumo@yahoo.co.id; Tel.: +60-16381-0227

Received: 22 March 2019; Accepted: 6 April 2019; Published: 30 July 2019

check for updates

\begin{abstract}
Organic Rankine Cycle (ORC) power generation systems may be used to utilize heat source with low pressure and low temperature such as solar energy. Many researchers have focused on different aspects of ORC power generation systems, but none so far has focused on the patent landscape of ORC system applications. As such, the objective of this study is to identify published patents on ORC system applications, particularly for solar energy. Four (4) technologies were identified in ORC application for solar energy: parabolic dish, parabolic trough, solar tower, and linear Fresnel reflector. A methodical search and analysis of the patent landscape in ORC system applications for solar energy published between 2007-2018 was conducted using the Derwent Innovation patent database. From the approximately 51 million patents in the database from various countries and patent agencies, 3859 patents were initially identified to be related to ORC applications for solar energy. After further stringent selection processes, only 1100 patents were included in this review. From these 1100 patents, approximately 12\% (130 patents) are associated with parabolic dishes, about 39\% (428 patents) are associated with parabolic troughs, approximately $21 \%$ (237 patents) are associated with solar towers, and about 28\% (305 patents) are associated with linear Fresnel reflectors. Published patents on solar tower technology are currently on an increasing trend, led by China. All of these patents were published in the past 11 years. From this study, further researches on ORC application are still ongoing, but ORC application for solar energy has the potential to advance; allowing the world to ease issues related to over-reliance on fossil fuel.
\end{abstract}

Keywords: Derwent innovation; Organic Rankine Cycle; ORC; parabolic dish; parabolic trough; solar tower; linear Fresnel reflectors

\section{Introduction}

Despite its negative connotation, the greenhouse effect is a natural phenomenon and is, in fact, crucial for the continuous survival of humankind on Earth. When sunlight reaches the surface of the Earth, some of the energy is absorbed by the land and the oceans while some of it is reflected back into space. Greenhouse gases in the atmosphere; which include water vapor $\left(\mathrm{H}_{2} \mathrm{O}\right)$, carbon dioxide $\left(\mathrm{CO}_{2}\right)$, methane $\left(\mathrm{CH}_{4}\right)$, nitrous oxide $\left(\mathrm{NO}_{2}\right)$, etc., prevent some of the heat from escaping into space 
and thereby, keep the Earth sufficiently warm to sustain life. This effect from the greenhouse gases is termed the greenhouse effect, and without it, average temperature on the surface of the Earth would drop considerably, possibly down to as low as $-21^{\circ} \mathrm{C}[1]$.

However, problems also happen with excessive concentrations of greenhouse gases in the atmosphere, due to deforestation and excessive burning of fossil fuel [2-5]. Deforestation, effectually, reduces the ability of the Earth to convert water vapor $\left(\mathrm{H}_{2} \mathrm{O}\right)$ and carbon dioxide $\left(\mathrm{CO}_{2}\right)$; both compounds in greenhouse gases, into oxygen $\left(\mathrm{O}_{2}\right)$ and sugar, through the process of photosynthesis. On the other hand, decades of burning of fossil fuel directly increases the concentrations of greenhouse gases such as carbon dioxide $\left(\mathrm{CO}_{2}\right)$, methane $\left(\mathrm{CH}_{4}\right)$, nitrous oxide $\left(\mathrm{NO}_{2}\right)$, etc. This increase in greenhouse gases results in notable climate changes such as increasing air and ocean temperatures, rising sea levels, extreme weather events and changing rainfall patterns [6-12].

The Paris Agreement established the auspices of the UN, which has been ratified by many countries, plans to reduce greenhouse gases in the atmosphere and limit the global temperature increase to $2{ }^{\circ} \mathrm{C}$ this century. One of the areas that researchers are looking at to achieve this is the use of alternative sources of energy that are less polluting to the environment. Energy generation from biomass [13-17], solid fuel [18-21], biofuel [22-27], hydro [28-31], wind [32-36] and nuclear [37-41] are just some of the areas that researchers are exploring, with strong support from different organizations and government agencies.

Naturally, in tropical countries which receive abundant solar irradiation, energy generation methods utilizing solar energy such as solar photovoltaic (PV), are extremely popular, with many successful implementations already [42-44]. Other possible method of utilizing solar energy involves the use of commonly discarded low-grade heat $[45,46]$. Indeed, there already exist a lot of studies in the literature on power generation plants utilizing low pressure and low temperature heat. A classification of power generation systems based on their working temperature is presented in Figure 1 [47].

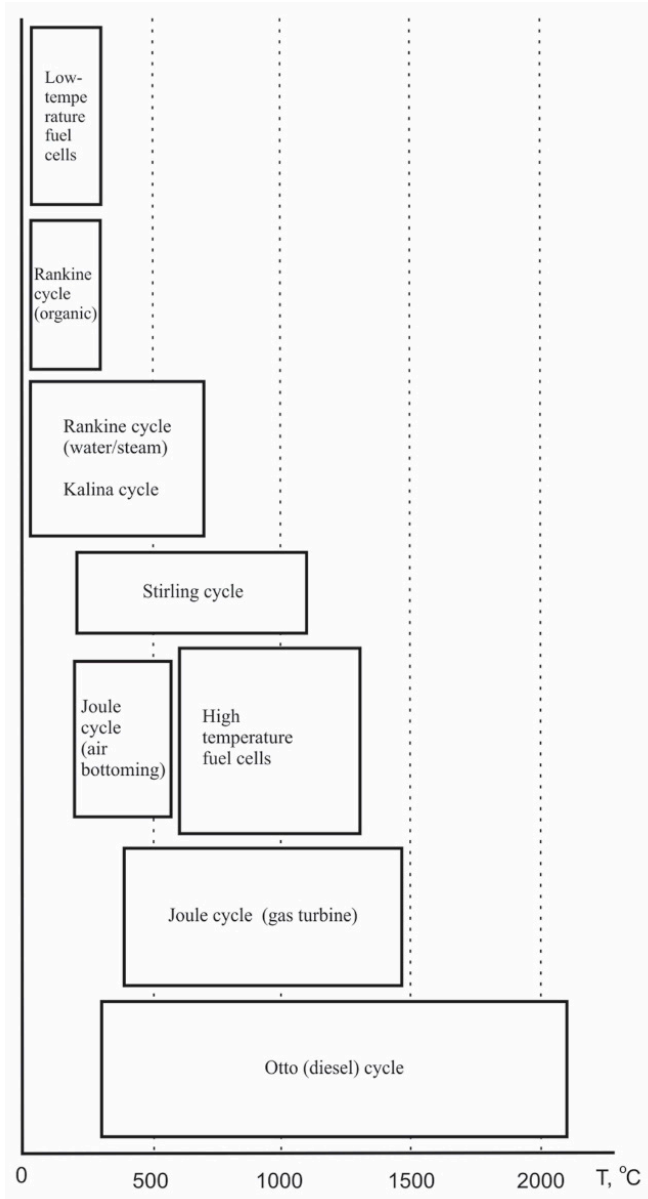

Figure 1. Classification of power generation systems based on working temperature, redrawn from [47]. 
As can be seen from Figure 1, Rankine Cycle, Kalina Cycle, and low-temperature fuel cells have relatively low working temperatures and have the potential to be used in plants utilizing low-grade heat. Thus far, Organic Rankine Cycle (ORC) systems have been a more popular choice as a power generation system, as they only require simple components, which are widely available on the market. The Rankine Cycle is composed of four stages: (1) isentropic compression at the pump, (2) isobaric evaporation of the boiler, (3) isentropic expansion on the turbine, and (4) isobaric condensation on the condenser. In terms of working fluid, ORC utilizes organic refrigerants with low condensation and boiling points; allowing ORC to utilize low heat grade with low pressure and low temperature [48-54].

Similar to other power generation plants utilizing low-grade heat, ORC power generation plants are not specifically designed to utilize solar only and have wider applications using other sources of energy. Indeed, they have been used in various applications such as ones employing biological waste heat, geothermal, engine exhaust gases, domestic boilers, and of course, solar thermal power [55-60]. Many researchers have expended efforts on various aspects of ORCs; their application, techno-economic analysis, thermo-dynamic analysis, working fluid selections, efficiency optimization of ORC power generation plant, etc. [61-65]. However, thus far, no work has been found that focuses on reviewing the design patent landscape related to ORC. For this study, focus is directed towards the design patent landscape of ORC power generation plants utilizing low-grade heat with low pressure and low temperature, from only solar energy. Four (4) applications have been shortlisted and identified as technologies in ORC application for solar energy as shown in Figure 2. In the next section, a methodical patent search is going to be performed on published patents concerning these technologies related to ORC applications for solar energy.

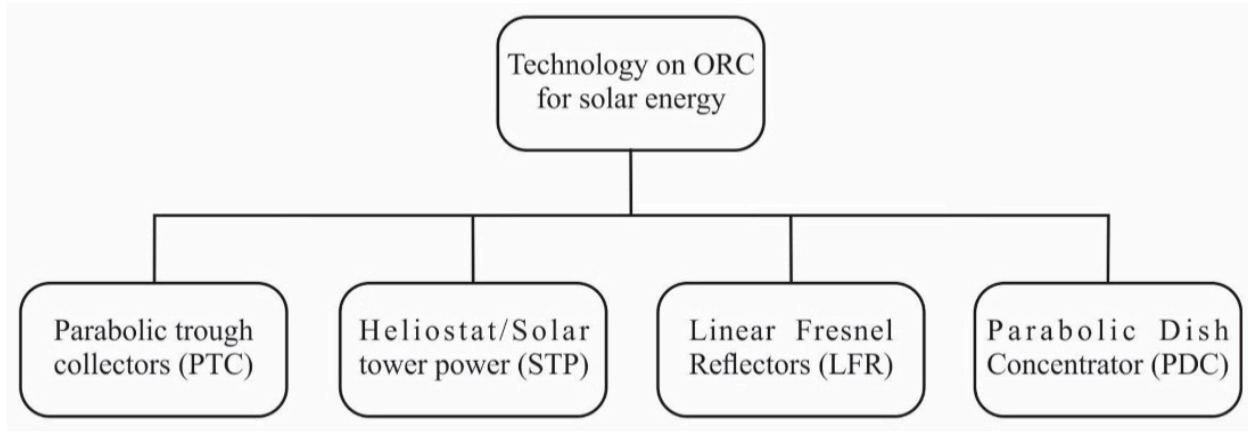

Figure 2. Technologies of organic Rankine cycle application for solar energy.

\section{Methodology}

Patent databases are well known as abundant and useful sources of data for forecasting disruptive technology, cutting-edge technology analysis and global management of worldwide invention portfolios. Analysis of patents is especially important in academia and even more so, for corporate entities; as a guide for abundant technology development measurements, and due to the high prospects of patents as an economic scale through commercialization [66].

Derwent Innovation (https://www.derwentinnovation.com), known in the past as Thomson Innovation, was utilized in this study, as an analytics and search platform for our study on patents related to ORC [67]. In order to perform this study, an institution must first subscribe to Derwent Innovation. Derwent Innovation provides more than 51 million patents originating from some major nations, major patent authorities and proprietary sources, as well as further 23 million basic worldwide inventions. It is also equipped with the capability of providing analysis on worldwide patents with connections to numerous records; with English translations from over 30 languages, originating from up to 50 patent-issuing authorities.

Using keywords in patent claims and titles, advanced patent search for technology in ORC application for solar energy was executed with the Derwent Innovation analytics and search platform tool. Search results were then extracted onto Microsoft Excel to allow systematic analysis. The search 
strategy used to search the patents on ORC technology applications for solar energy was performed using selected keyword terms that are presented in Table 1. Dashboard and spreadsheet facilities in Excel were then used to tabulate results from the search; with details relevant to the patents including title, abstract, names of applicants, priority date, names of the inventor, International Patent Classification (IPC) and patent claims. All the listed patent details were then systematically analyzed and re-organized into correlated categories.

Table 1. Strategy adopted to perform the search using Derwent Innovation.

\begin{tabular}{cc}
\hline Technologies in ORC Application for Solar Energy & Keyword Terms \\
\hline Parabolic trough & $\begin{array}{c}\text { Search (Solar energy AND Parabolic trough AND } \\
\text { Technology) \{Title, Abstract, Claims\} }\end{array}$ \\
Solar tower & $\begin{array}{c}\text { Search (Solar energy AND Solar tower AND } \\
\text { Technology) } \\
\text { \{Title, Abstract, Claims\} }\end{array}$ \\
\hline Fresnel trough & $\begin{array}{c}\text { Search (Solar energy AND Linear Fresnel AND } \\
\text { Technology) \{Title, Abstract, Claims\} }\end{array}$ \\
\hline Parabolic Dish & $\begin{array}{c}\text { Search (Solar energy AND Parabolic Dish AND } \\
\text { Technology) \{Title, Abstract, Claims\} }\end{array}$ \\
\hline
\end{tabular}

Using the PRISMA statement [68] as our basis, the methodical patent landscape review process shown in Figure 3 was followed. Searches were performed for published patents from 2017 up to July 2018, and full patent or patent abstracts were methodically categorized, analyzed and reviewed. The identification stage of the search retrieved a total of 3859 patents; with 1686 patents deemed as duplicate patents, and thus, removed from the results. Title, abstract and claims of the patents were then extracted and meticulously assessed to investigate relevance of the patents for further analysis. In particular, relevance of the patents to Organic Rankine Cycle application for Solar Energy was examined. From the total of 2173 patents in the screening stage, 1001 patents were excluded from our results due to its inapplicability to organic Rankine cycle applications while a further 72 patents were excluded for not satisfying eligibility criteria for solar energy technology. A total of 1100 patents on technology in ORC applications for solar energy, were finalized to be included for further review.

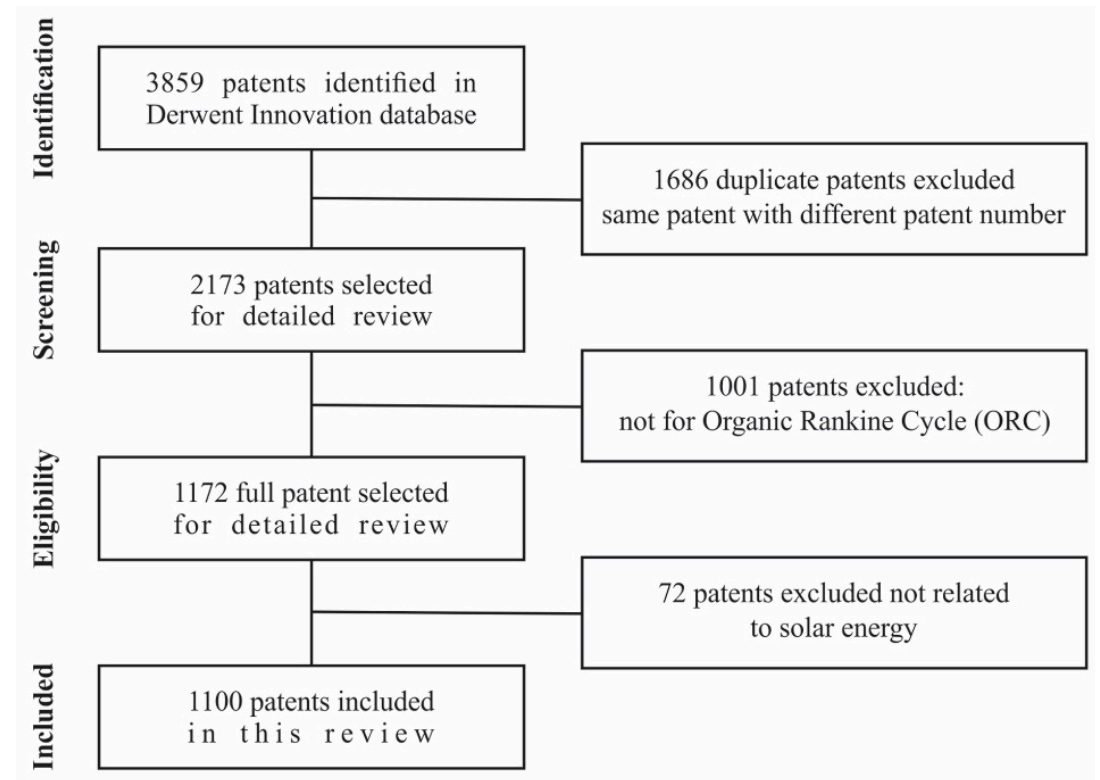

Figure 3. Flowchart of process adopted to review patents results; based on PRISMA Statement [68]. 
It is noted that only patents with publication dates between 2007 and July 2018 were included in the search. As only the Derwent Innovation platform was used, patents not incuded in the Derwent Innovation database were excluded. Also excluded were prospectively associated patents that were not cited in the patent abstract, keywords and title. A few non-English full patents were also removed; despite their probable relevance to the topic based on the abstracts and claims which were available in English language, due to inaccessibility issues related to language barriers, and limitations of the data and database.

\section{Results and Discussion}

\subsection{Patent Landscape}

A total of 1100 patents on four technologies used in ORC applications-parabolic dish, parabolic trough, solar tower, and linear Fresnel reflector-were selected for review. Approximately $12 \%$ or 130 patents from the total 1100 patents are associated with parabolic dishes, 39\% or 428 patents associated with parabolic troughs, $21 \%$ or 237 patents associated with solar towers and the remaining $28 \%$ or 305 patents are associated with linear Fresnel reflectors. A pie chart showing the distribution of patents according to technologies, is given in Figure 4. A plausible explanation on why more patents about parabolic troughs were published may be due to its affordability as compared to the other technologies and due to the fact that they are viewed as more energy efficient [69].

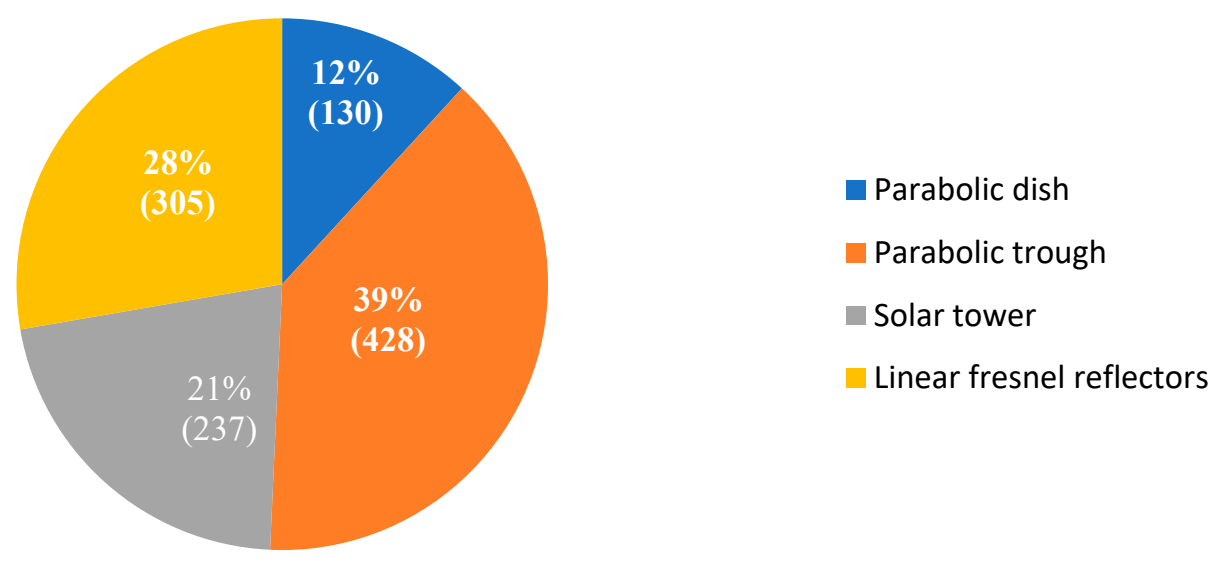

Figure 4. Distribution of different technologies in ORC application for solar energy patents.

Figure 5 shows the distribution of selected patents based on their publication dates. In 2007, only 16 patents related to ORC applications for solar energy were published. A steady year-on-year increase in the number of published patents is observed between 2008 up to 2013, with a minimal decrease of less than 10 patents between 2011 and 2012. After reaching its peak in 2013, small decrements from previous years are observed in 2014 and 2015. These decrease may be due to decreasing awareness towards the importance of solar energy in ORC. Between 2015 and 2017, the number of published patents related to OCR applications for solar energy remained almost the same, within a range of 115-125 patents per year. A large drop in the number of published patents is observed in 2018; due to the fact the data collection period in 2018 was only up to the 2 nd quarter of the year, i.e., data only available until July 2018. The patent publications in 2018, thus far, appear promising. Around 59 patents were published during half of the year; approximately half the number of patents published in the previous year, and as such, the number of published patents in 2018 is expected to be almost similar to the previous years (i.e., in 2015-2017 within the range of 115-125 patents per year). The high annual number of published patents in ORC application for solar energy is important as the use of solar energy is increasing rapidly due to improvement in renewable energy technology. 


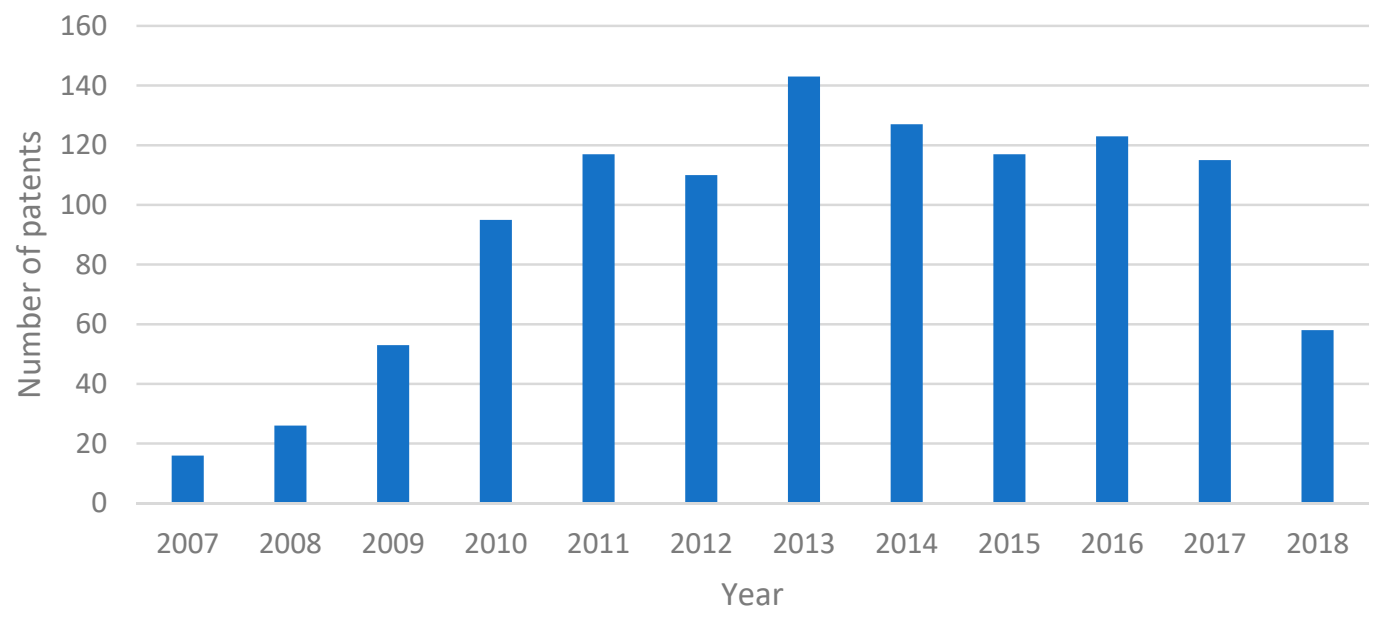

Figure 5. Annual number of published patents between 2007 and 2018.

A pie chart depicting the distribution of countries/organizations where patents were filed or granted, is shown in Figure 6A. For each country/organization, the number of different solar energy technologies that were patented, is shown in Figure 6B. It can be seen that the top three countries/organizations with the highest number of published patents are China $(\mathrm{CN})$, the World Intellectual Property Organization (WIPO) and the United States (US), with approximately 37\%, $22 \%$ and $20 \%$ of the total selected patents, respectively. In total, the top three countries/organizations patented $79 \%$ of the total 1100 selected published patents.

China has the highest number of published patents in ORC applications for solar energy with 402 patents; composed of 217 patents about solar towers, 83 patents on linear Fresnel reflectors, 81 patents concerning parabolic troughs and 21 patents on parabolic dishes. It is interesting to note that despite the high number of patents about solar tower technology in China, solar tower technology only ranks second in terms of overall number of patents for different technologies from our 1100 selected published patents; superseded by parabolic trough technology, as can be seen from Figure 4. This is because parabolic trough technology is the preferred technology in all other countries/organizations with the exception of China. Parabolic trough technology represents the highest number of patents with $48 \%$, $49 \%, 78 \%, 59 \%, 47 \%, 53 \%, 35 \%$ and $54 \%$ of selected published patents, in Australia, European Union Office, Japan, Korea, United States, WIPO, India and Denmark, respectively.

The number of published patents for different solar energy technologies in ORC application from 2007 until 2018 are presented in Figure 7, with patent data for parabolic troughs, linear Fresnel reflectors, solar towers and parabolic dishes, given in Figure 7A-D, respectively.

As can be seen in Figure 7A, the number of published patents for parabolic troughs followed an increasing trend post-2007; peaking at 60 patents in 2011, before following a decreasing trend after 2011. For 2018, it is predicted that the number of published patents to be less than the previous year; based on the half-year data which were available.

For linear Fresnel reflector technology in Figure 7B, the number of published patents also increased year-on-year after 2007 reaching a peak value of 48 patents in 2013, before suddenly dropping to only 22 published patents in 2014. However, it increased again after 2014 before going on a downward trend after 2016. The number of published patents in 2018 is predicted to be less than the previous year. However, save for the temporary blip in 2014-2015, the number of published patents seem to follow a general pattern of increasing publications after 2007, peaking in 2013 before following on a downward trend thereafter. 


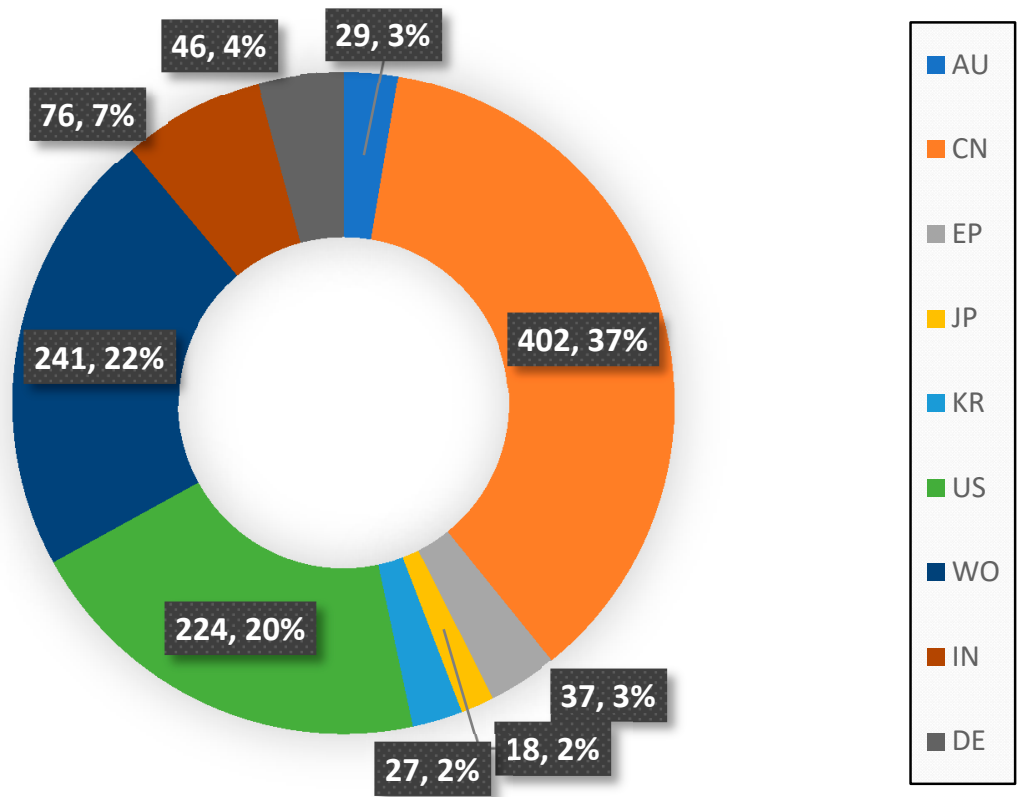

(A)

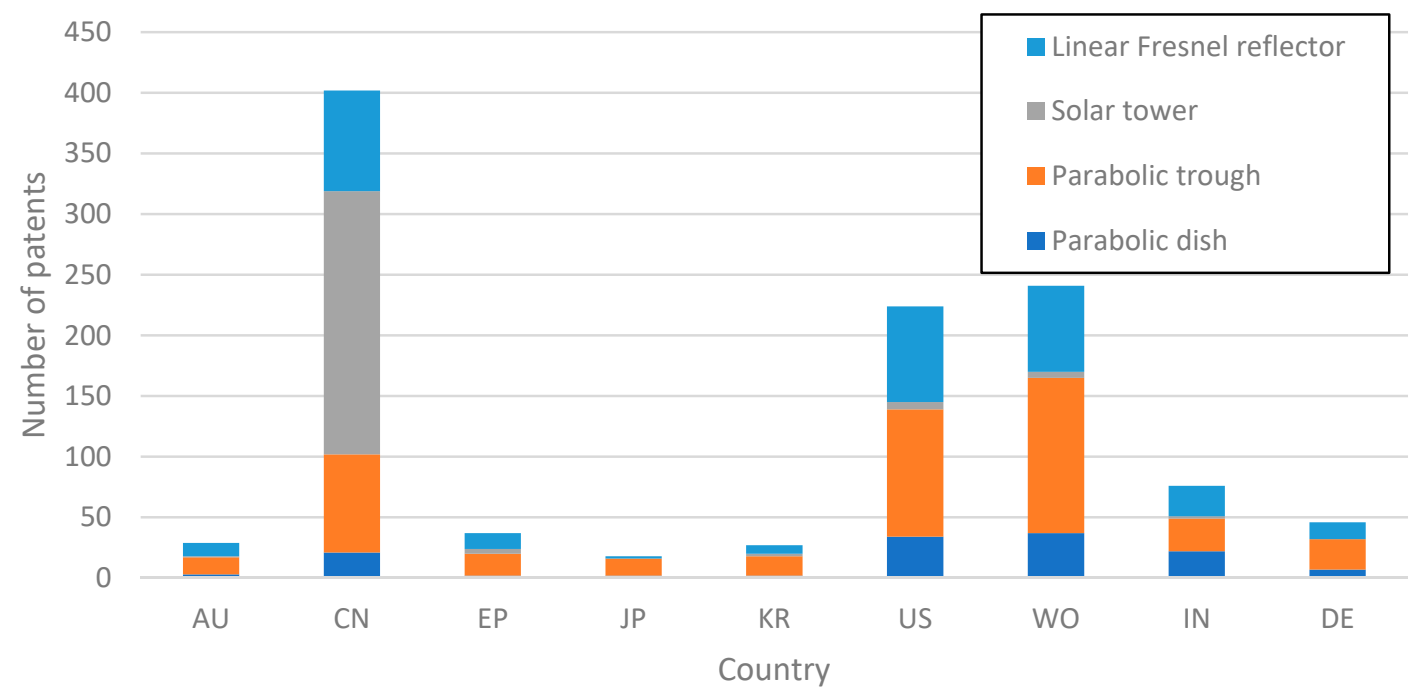

(B)

Figure 6. Distribution of origins of selected patents according to countries/organisations with Country codes: AU (Australia); CN (China); EP (European Union Office); JP (Japan); KR (Korea); US (the United States); WO (World Intellectual Property Organization, WIPO); IN (India); DE (Denmark) (A); Number of patents and solar energy technologies in ORC application for different countries/organizations (B).

The number of published patents for parabolic dishes generally follows an almost similar pattern to that of linear Fresnel reflectors, as can be seen from Figure 7D. The maximum number of published patents for the parabolic dish was in 2014 with 21 published patents.

These are unlike the number of published patents for solar tower technology. From Figure 7C, the number of published patents also increased annually after 2007. However, assuming the full-year data would be double that of the half-yearly data of 29 patents, the number of published patents in 2018 was expected to increase, exceeding the maximum annual published patents of 41 patents in 2016. As such, it may be assumed that the number of published patents for solar tower technology has yet to reach its peak. 


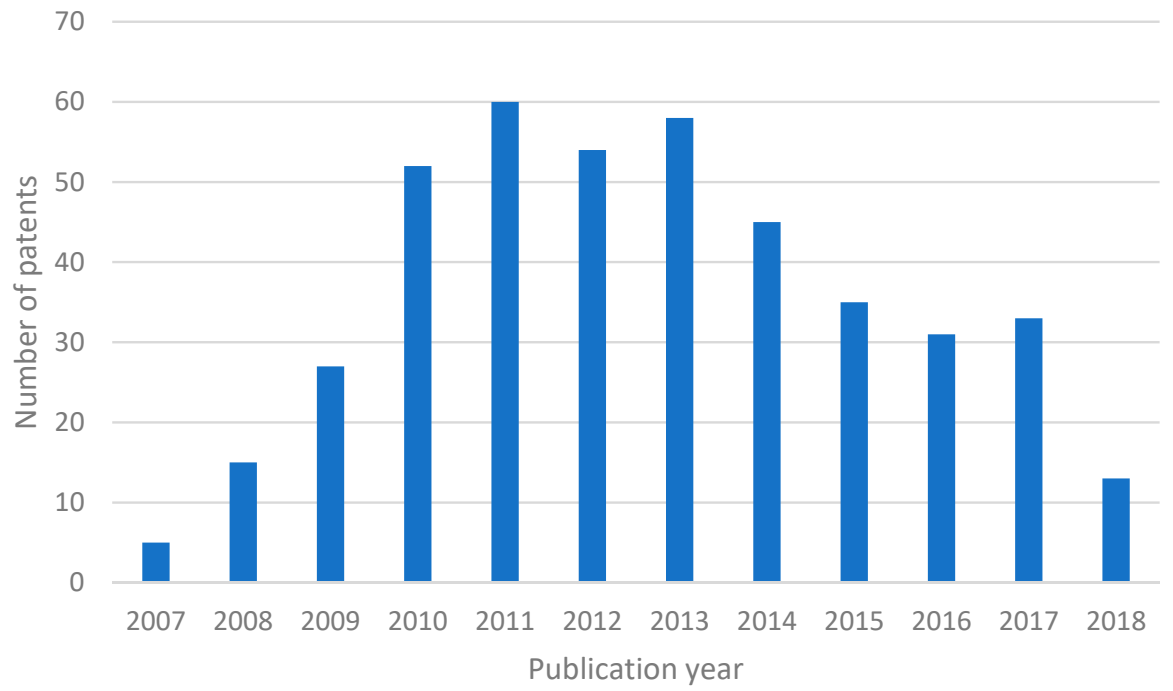

(A)

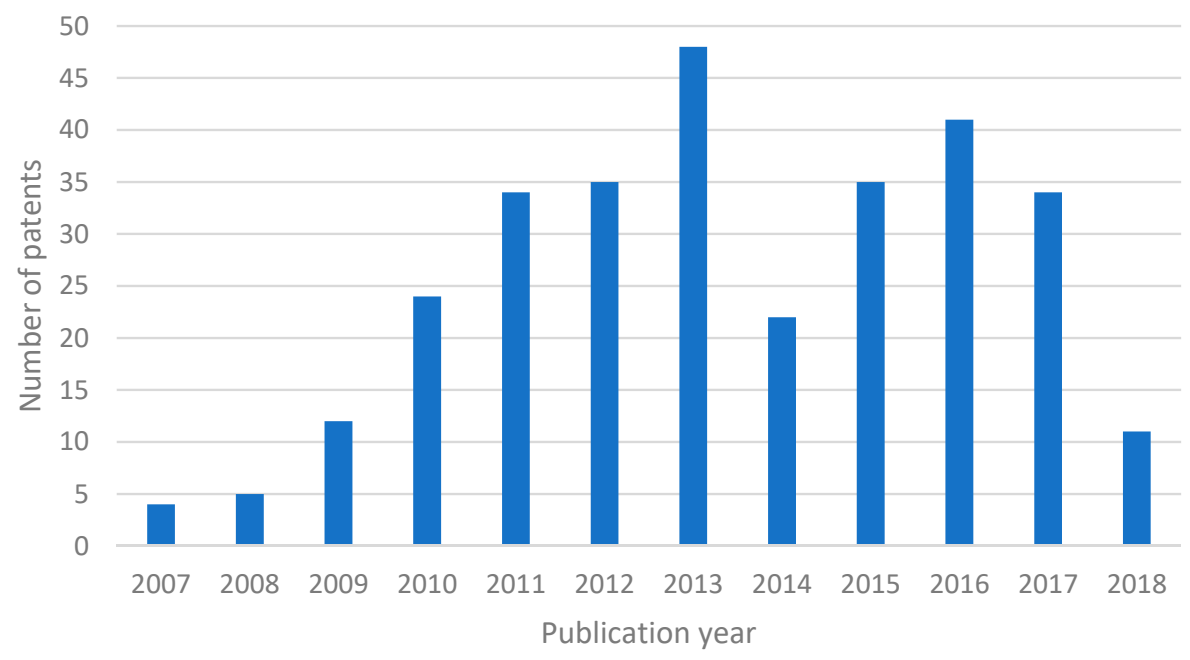

(B)

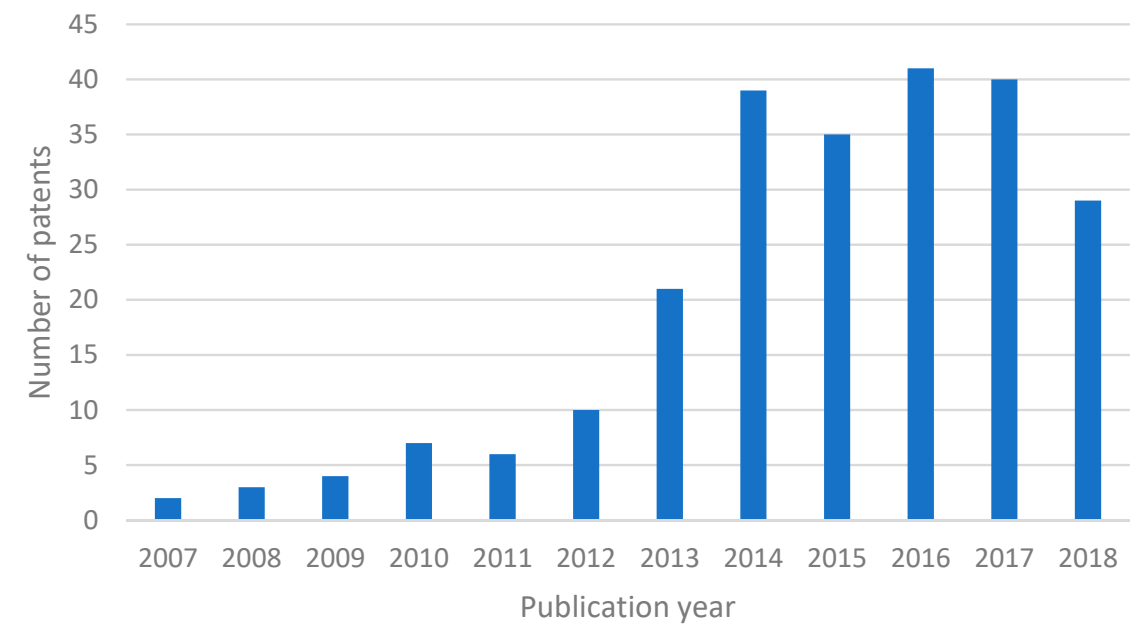

(C)

Figure 7. Cont. 


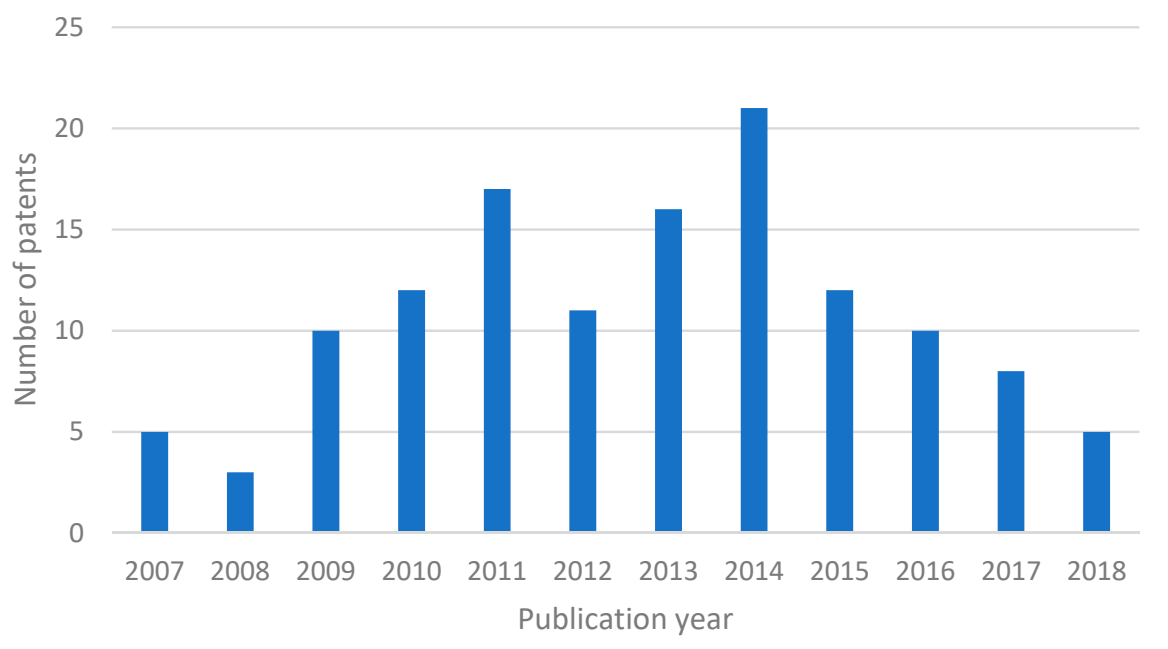

(D)

Figure 7. Number of parabolic trough patents vs publication year (A); Number of linear Fresnel reflector patents vs publication year (B); Number of solar tower patents vs publication year (C); Number of parabolic dish patents vs publication year (D).

Overall number of patents vs publication year, is presented in Figure 8. Generally, it can be deduced that the numbers of published patents for these technologies initially increased annually post 2007. In the case of parabolic troughs, linear Fresnel reflectors and parabolic dishes, the maximum number of published patents were reached around the 2011-2014 period, which were then followed by uneven annual decrements. An exception is the number of published patents for solar tower which had risen continuously from 2007 until 2018; albeit with slower initial increment in the earlier period. Also from the figure, there is a high number of published patents in parabolic trough technology in 2011-2013. However, towards 2018, there is more interest in the area of solar tower technology, as evident from the high number of published patents in solar tower technology in 2017-2018. It is noted that most of the published patents for solar tower technology came from China.

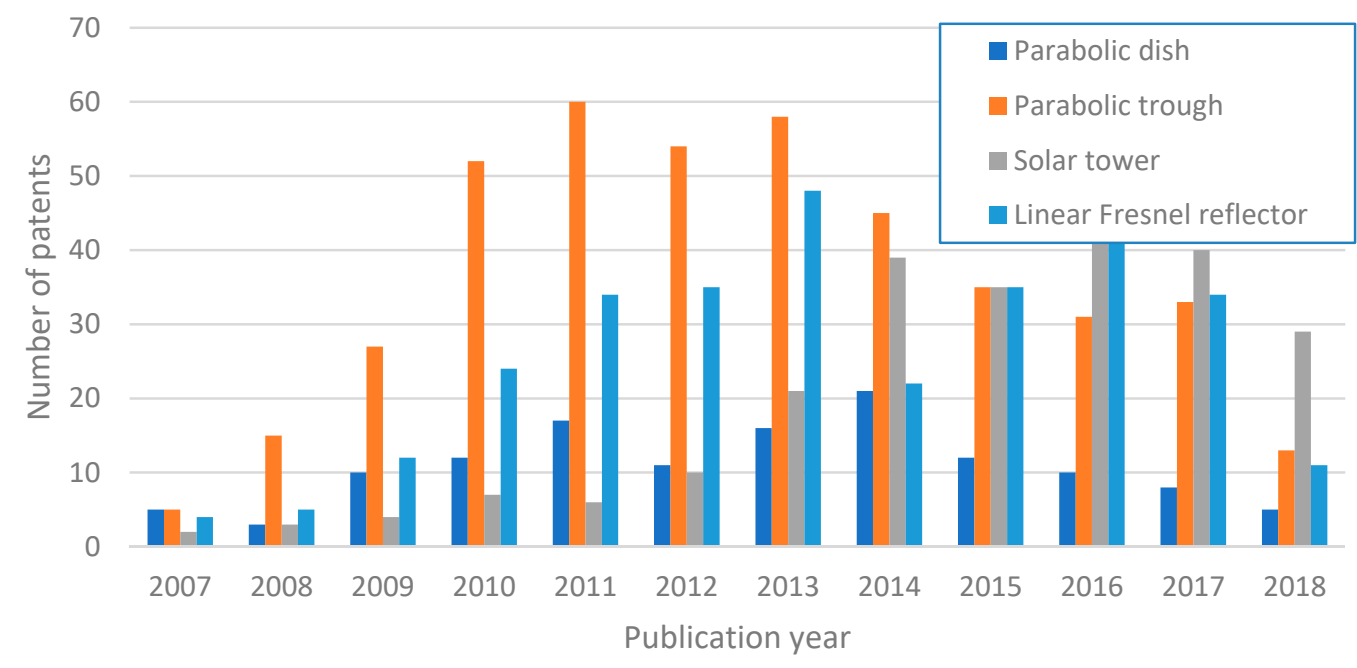

Figure 8. Number of patents vs publication year.

Collectively, it can be deduced from Figure 5 that the number of published patents in ORC applications has been almost constant in the period 2015-2018. This observation is likely due to the fact that policies from various countries are still maintaining renewable technologies as their prime sources of energy. Potential environmental impacts associated with solar power; such as climate 
change, global warming, uncertainties by countries worldwide, habitat loss, can vary depending on the implementation of technologies. One thing is for sure, it is crucial at this current time to conserve the scarce natural resources that we have, which have been over-utilized for the past decades. Huge difference may be realized by putting minimal effort on conservation; to help preserve the natural resources for future generations.

\subsection{Technology Updates}

This section discusses current research updates available in the patent databases on the topic of ORC system applications on solar energy. As presented in Figures 2 and 4 in previous sections, ORC system applications may be categorized into four broad applications: parabolic dishes, parabolic troughs, solar towers and linear Fresnel reflectors. Details of technology updates for each category are discussed in the following sections.

\subsubsection{Parabolic Dish}

Parabolic dish systems contain a concave dish-shaped concentrator, which reflects sunlight onto a receiver located at the focal point of the parabolic dish, as shown in Figure 9. Supplemented by a solar tracking system, concentrated reflections from the relatively large area of the parabolic dish onto the heat receiver are capable of increasing the temperature of the receiver up to $200-700{ }^{\circ} \mathrm{C}$; with the heat engine of the receiver used to convert heat energy onto electricity. The efficiency of the systems to convert heat onto electricity is commonly quite high, capable of producing average annual yield rates that are typically $18-23 \%$ higher than those of other solar energy systems. The high efficiency of the system coupled with the modularity of its components, makes parabolic dish systems highly suitable for distributed electricity generation from solar energy [70].

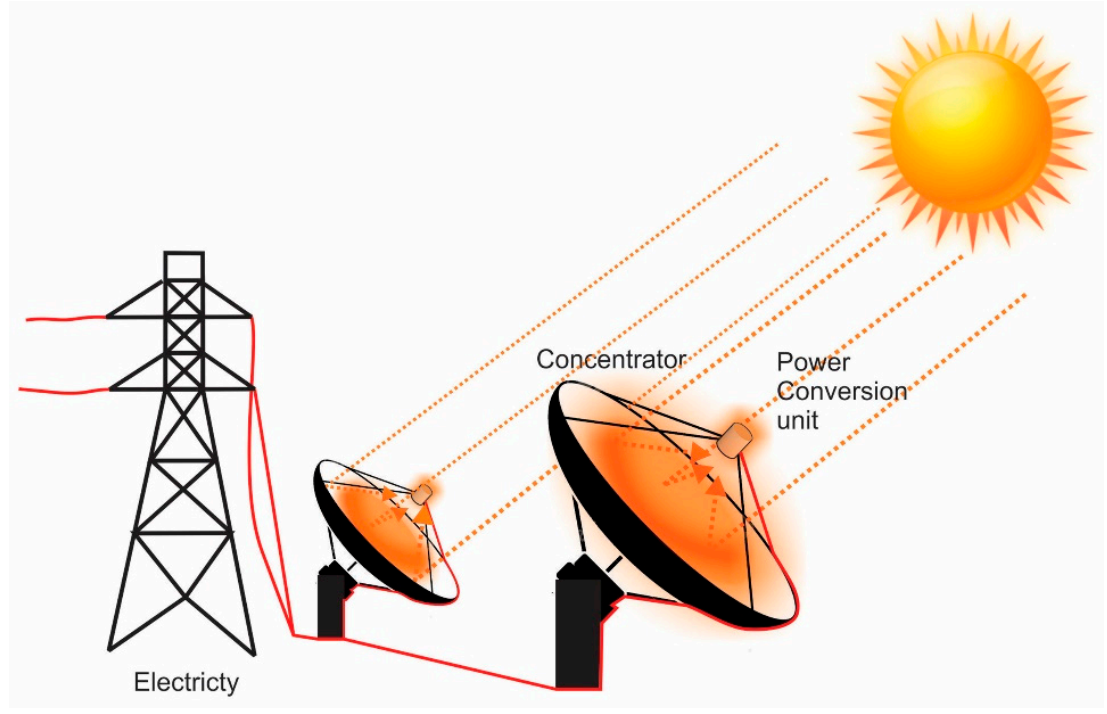

Figure 9. Solar thermal electricity generation of a parabolic dish.

One of the research focuses on parabolic dish systems for ORC applications, is in further improving efficiency of the solar receiver with the use of tubular cylindrical cavities [70]. A coated copper closed-tube open cylindrical cavity was used as heat engine with thermal oil as its working fluid. Another working fluid considered was the refrigerant gas R141B under saturated vapor conditions. Thermal operations of the system were initially modelled to allow optimization of the cylindrical cavity receiver. Important parameters determining performance of the system include the shape, reflectivity and optical error of the concentrator. Also important are the tracking error of the solar tracking system, inlet temperature and flow rate of the thermal oil as well as the aperture area, tube diameter, cavity depth of the receiver. 


\subsubsection{Parabolic Trough}

Parabolic troughs are some of the most popular solar thermal electrical generation systems. It is the most developed concentrating solar thermal technology with the most number of published patents. In the US, research on parabolic trough technology was started back in the early 1980s by the Department of Energy, with parabolic trough electrical generation systems already working steadily and privatized by the mid-1990s. It is expected that the currently available parabolic trough electrical generation systems will be operational for the next 20 years.

As indicated in Figure 10, parabolic trough systems use curved highly reflective mirrors that are designed to reflect and direct the sunlight onto the linear heat receiver fixed on the focal axis of the trough. The linear heat receiver is made up of heat-absorbing pipes. The heat transfer fluid absorbs thermal energy produced from the concentrated solar reflections on the pipe, which consequently flows to the steam generator. The heated fluid drives the turbine of the steam generator, producing super-heated steam, which is then converted to electricity. Once the thermal energy from the heated fluid is used up, it is then recirculated and reused by the system [70].

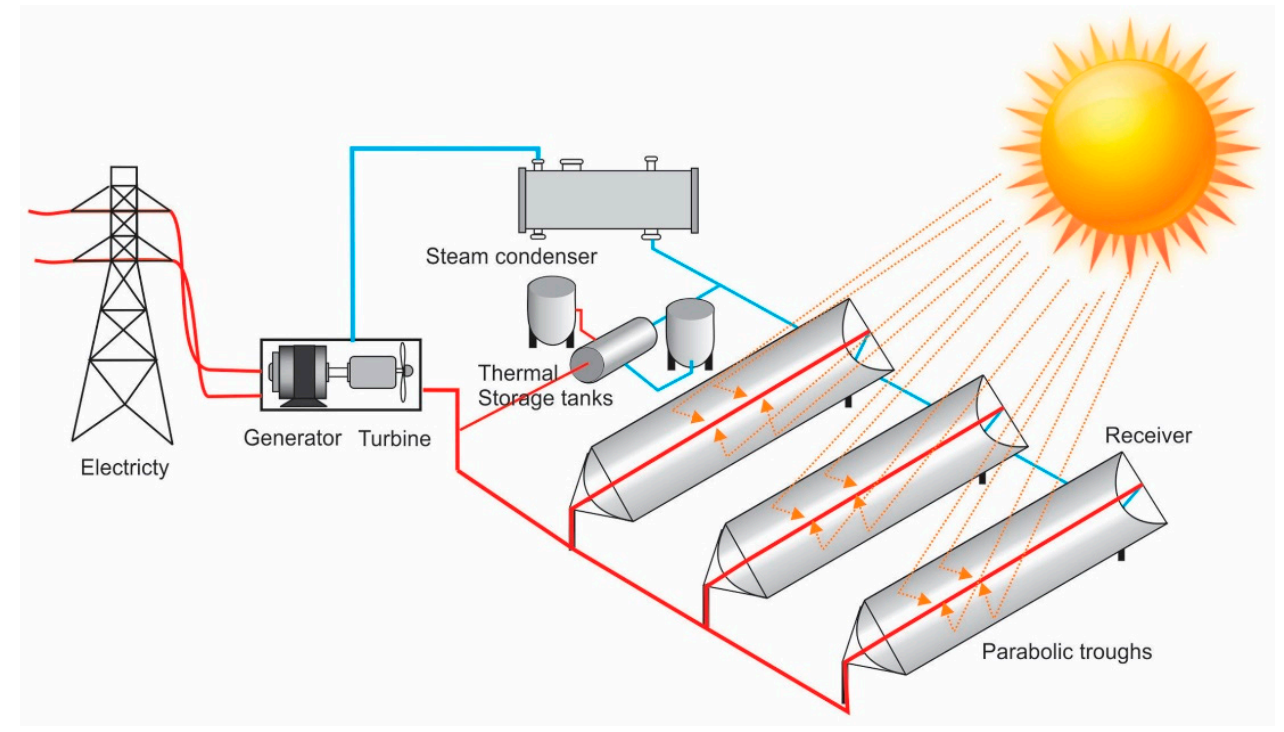

Figure 10. Solar thermal electricity using parabolic troughs.

One of the articles compares the performance of solar ORC (s-ORC) systems using parabolic trough technology and photovoltaic (PV) systems, both with capacity of $50 \mathrm{kWe}$, in terms of its technical and economic performances [71]. Solar ORC and PV systems utilize thermal energy and battery storage systems, respectively, for their energy storage requirements. Results indicate that ORC using parabolic troughs is potentially more cost-effective in scenarios where power supply reliability is essential, provided the system is coupled with efficient thermal energy storage [71]. A performance comparison between parabolic troughs and linear Fresnel reflectors was studied in [72] by assuming integration of the two different collectors into a mid-size concentrating solar power plant, based on ORC power generation. Using solar data from Italy with an average annual energy production per unit area of $1729 \mathrm{kWh} / \mathrm{m}^{2} \mathrm{y}$, the power plants were modelled with different solar multiples and storage capacities values, and simulations were performed. With an assumed ORC power generation capacity of $1 \mathrm{MW}$ with $24 \%$ conversion efficiency, the parabolic trough has been shown to be more cost effective in terms of energy produced per unit area of solar collector; capable of producing $180-190 \mathrm{kWh} / \mathrm{m}^{2}$ of energy. The superior performance of the parabolic trough may be attributed to its higher optical efficiency.

\subsubsection{Solar Tower}

Figure 11 depicts a typical solar power tower system; which is a type of solar furnace utilizing a high tower to gather focused sunlight. As can be seen from the figure, arrays of movable, flat heliostats 
are used to reflect and concentrate sunlight onto the solar power tower. These concentrated rays heat liquid onto steam, which is then used to power up the turbine to generate electricity. As compared to parabolic trough, solar power tower is relatively cheaper. This is because heliostats used in solar tower system utilize standard flat flare glasses which are less expensive than trough mirrors used in parabolic trough system which need to be specifically manufactured with specific curvatures depending on the designs of the parabolic trough system [73].

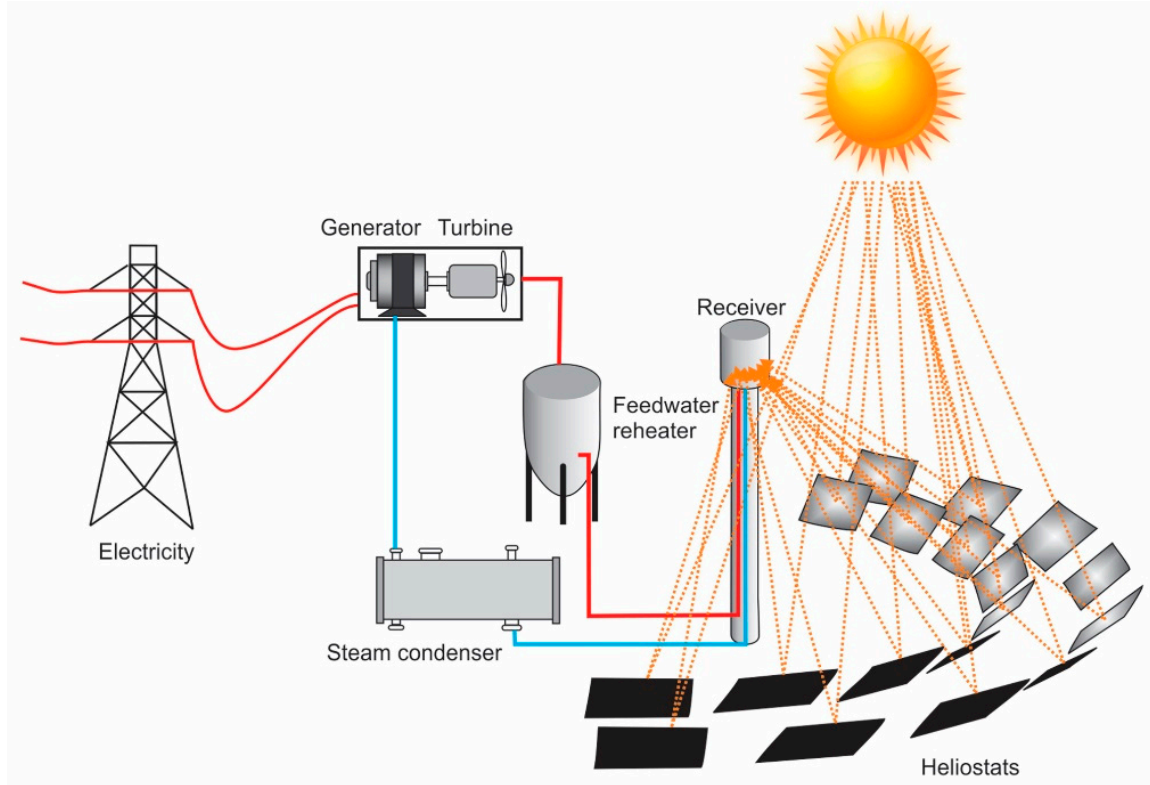

Figure 11. Solar thermal electricity generation by solar towers.

Two large and prominent electric power generation plants/projects in the United States have been developed utilizing solar tower technology; the Ivanpah solar electric power generation system and the Crescent Dunes solar energy generation project. Located in the Californian desert, the Ivanpah solar electric generation system is considered the biggest concentrated solar thermal plant in the United States, capable of producing a massive $392 \mathrm{MW}$ of electricity. The plant utilizes a total of 173,500 heliostats; with each heliostat consisting of two mirrors, to reflect and concentrate sunlight onto its three solar towers. The Crescent Dunes solar energy generation project, which is located in Nevada, has a much smaller capacity than the Ivanpah system, with a capacity of $110 \mathrm{MW}$.

Other than the United States, other countries have also developed electric power generation plants utilizing solar tower technology. Notably, Spain has developed quite a number of solar tower power generation systems. For instance, Planta Solar 10 and Planta Solar 20 are capable of generating $11 \mathrm{MW}$ and $20 \mathrm{MW}$ of electricity, respectively, by integrating steam turbine power generator to solar tower technology. Another project is Gemasolar, which can generate $20 \mathrm{MW}$ of electricity.

\subsubsection{Linear Fresnel Reflector}

Linear Fresnel reflector technology is notable for its similarity to the parabolic trough system. Whilst mirrored troughs are used to reflect and concentrate sunlight in parabolic trough systems, arrays of slightly curved or flat mirrors are placed at different angles to reflect and concentrate sunlight onto a rigid receiver, made up of a coated long tube and located on top of the arrays of mirrors. A single axis Sun tracking system is used to ensure that the mirrors track the Sun movement, such that maximum sunlight is concentrated onto the receiver. Similar to parabolic trough system, heat is used to convert the heat transfer fluid into steam as it passes through the receiver; which are consequently used to drive the steam turbine for electricity production [74]. Solar thermal electricity generation by linear Fresnel reflectors is illustrated in Figure 12. 


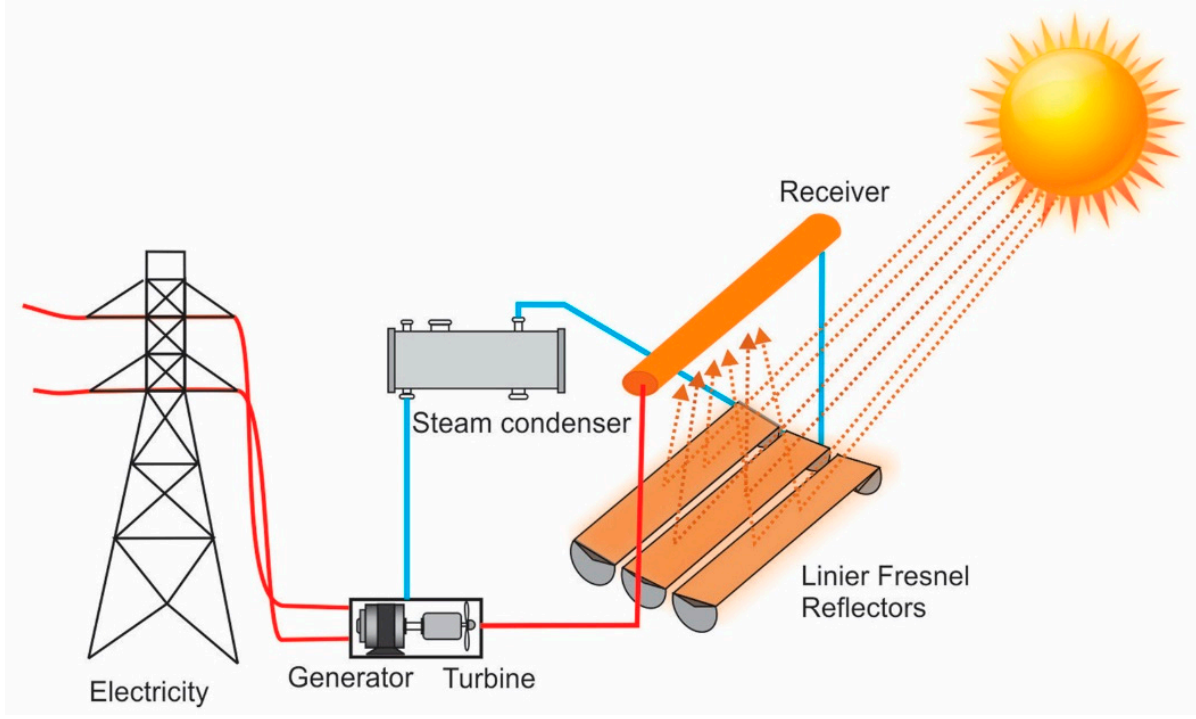

Figure 12. Solar thermal electricity by linear Fresnel reflectors.

Recent work involving the use of linear Fresnel reflectors is given in [74] for the liquefaction of natural gas using solar technology. A cascaded ORC configuration was used to produce liquefied natural gas as well as electrical power; by integrating the system to arrays of linear Fresnel reflectors for supplying energy to the system. It is shown that the novel configuration can reduce the production cost of liquefied natural gas.

In [72], the performance of mid-size solar power plants integrated to arrays of linear Fresnel reflectors was compared to that of similar plants integrated with parabolic troughs. Although the performance of systems integrated to linear Fresnel reflectors has been shown to be inferior to systems integrated with parabolic troughs, plants with linear Fresnel reflector technology have been shown to be capable of producing a respectable annual amount of 55-60 $\mathrm{kWh}$ of electricity per $\mathrm{m}^{2}$ of the solar collector. This electricity generation estimation was produced using solar data from Italy with an average annual energy production per unit area of $1729 \mathrm{kWh} / \mathrm{m}^{2} \mathrm{y}$.

\subsubsection{Technology Updates}

In this section, some selected recently registered patents in the database are discussed and elaborated. The first one is on solar energy overlapping Rankine cycle power generation systems with different exothermic modes [75]. This newly patented system is based on ORC power generation using solar energy as its source of heat. Different exothermic modes have been used for the system. The patent also includes parabolic groove type heat collector arrays to power steam ORCs. This newly patented technology allows annual ORC savings, such as shortening of the payback period, makes operating time longer, as well as generating more energy. Another patent [76] is on combined solar thermal power generation system using ORC. This patent combines solar thermal power generation using ORC for a power generation system, a heat exchanger, a parabolic trough solar collector and a dish power generation. This ORC power generation uses the heat released by a Stirling engine. The ORC utilized an extra heat source that increases steam turbine capability and increases the total efficiency of power generation [76].

One of the most interesting newly patented technologies is based on photovoltaic and photo-thermal coupled thermoelectric generation systems and methods that use ORC [77]. This newly patented solar power generation is a power generation subsystem, a heat collection subsystem, and a heat supply system; with these systems linked together in series. The heat collector of the system is parabolic and is connected to a photovoltaic and photoelectric system. The ORC is a heat exchanger, a condenser, a turbine generator, a pump and a storage tank that are all connected in series. The system maximizes the use of absorbed solar energy and therefore, increases energy efficiency and reduces 
the life cycle cost of the entire system. Another newly patented technology is based on ORC power generation device that use a flow path control method for heat collecting fluid [78]. The developed system is a combination of ORC and solar energy heat collector; with the solar collector consisting of shell pipes that are required for liquid distribution, and parabolic concentrator. The patent claims through this new method a stable and efficient power generation that can be achieved by just adjusting flow rate of the system. Latest technology updates on newly patented implementation of solar energy in ORC are tabulated in Table 2.

Table 2. Patent updates on organic Rankine cycle (ORC) system applications for solar energy.

\begin{tabular}{|c|c|c|c|}
\hline Date & Patent Titles & Patent Number & Inventors \\
\hline 2018-03-02 & $\begin{array}{l}\text { Solar energy overlapping Rankine cycle } \\
\text { power generation system with different } \\
\text { exothermic modes }\end{array}$ & CN207064169 (U) & $\begin{array}{l}\text { Li Jing; Pei Gang; } \\
\text { Gao Guangtao; Ren Xiao; Ji Jie }\end{array}$ \\
\hline 2018-03-08 & $\begin{array}{l}\text { Combined Solar Thermal Power } \\
\text { Generation System }\end{array}$ & US2018066635 (A1) & $\begin{array}{l}\text { Zhang Yanping; } \\
\text { Zhang Cheng; Huang Shuhong }\end{array}$ \\
\hline 2017-08-18 & $\begin{array}{l}\text { Photovoltaic and photo-thermal } \\
\text { coupled thermoelectric generation } \\
\text { system and method }\end{array}$ & CN107061201 (A) & $\begin{array}{l}\text { Miao Zheng } \\
\text { Zhang Kai }\end{array}$ \\
\hline $2017-01-18$ & $\begin{array}{l}\text { Organic Rankine Cycle power } \\
\text { generation device and flow path control } \\
\text { method for heat collecting fluid }\end{array}$ & CN106337788 (A); CN106337788 (B) & $\begin{array}{l}\text { Xu Rongji; Yan Meiyu; } \\
\text { Luan Yitao; Xu Shuhui } \\
\text { Wang Ruixiang; Wang } \\
\text { Huasheng }\end{array}$ \\
\hline 2017-01-11 & $\begin{array}{l}\text { Organic Rankine Cycle } \\
\text { power-generation device and flow } \\
\text { control method for heat collecting liquid }\end{array}$ & CN106321381 (A) & $\begin{array}{l}\text { Xu Rongji; Yan Meiyu } \\
\text { Zhang Xiaohui; Wei Yicong; } \\
\text { Wang Ruixiang; Xu Shuhui }\end{array}$ \\
\hline 2016-07-06 & $\begin{array}{l}\text { Formula of directly expanding solar } \\
\text { thermal power generation system based } \\
\text { on overlapping Rankine cycle }\end{array}$ & CN205370873 (U) & $\begin{array}{l}\text { Ji Jie; Li Jing; Li Pengcheng; Pei } \\
\text { Gang }\end{array}$ \\
\hline 2016-04-06 & $\begin{array}{l}\text { Direct-expansion solar thermal power } \\
\text { generation system based on cascade } \\
\text { Rankine cycle }\end{array}$ & CN105464914 (A) & $\begin{array}{l}\text { Ji Jie; Li Jing; Li Pengcheng; Pei } \\
\text { Gang }\end{array}$ \\
\hline $2013-06-12$ & $\begin{array}{l}\text { Solar power and biomass power } \\
\text { complementing organic Rankine cycle } \\
\text { cogeneration system }\end{array}$ & CN103147945 (A); CN103147945 (B) & $\begin{array}{l}\text { Ye Xuemin; Wang Jia } \\
\text { Li Chunxi; Tong Jialin }\end{array}$ \\
\hline $2012-10-17$ & $\begin{array}{l}\text { Slotted solar } \\
\text { intermediate/low-temperature ORC } \\
\text { (organic Rankine cycle) thermal power } \\
\text { generator }\end{array}$ & CN102734095 (A) & Jiancheng Zhang \\
\hline 2011-10-05 & $\begin{array}{l}\text { Slotted solar middle-low-temperature } \\
\text { ORC (Organic Rankine Cycle) thermal } \\
\text { power generation device }\end{array}$ & CN202001231 (U) & Jiancheng Zhang \\
\hline $2010-11-10$ & $\begin{array}{l}\text { Heat pipe solar organic Rankine cycle } \\
\text { low temperature thermal power } \\
\text { generation system }\end{array}$ & CN201627689 (U) & $\begin{array}{l}\text { Jing Li; Jie Ji; } \\
\text { Gang Pei }\end{array}$ \\
\hline $2010-09-15$ & $\begin{array}{l}\text { Direct expansion type solar low } \\
\text { temperature thermal power generation } \\
\text { and photovoltaic power generation } \\
\text { combined system }\end{array}$ & CN201582063 (U) & $\begin{array}{l}\text { Jie Ji; Jing Li; } \\
\text { Gang Pei }\end{array}$ \\
\hline $2010-08-11$ & $\begin{array}{l}\text { Direct-expansion type solar energy } \\
\text { low-temperature thermal power } \\
\text { generation and photovoltaic power } \\
\text { generation compound system }\end{array}$ & CN101798996 (A) & $\begin{array}{l}\text { Jie Ji; Jing Li; } \\
\text { Gang Pei }\end{array}$ \\
\hline 2010-06-30 & $\begin{array}{l}\text { Heat pipe type solar energy ORC } \\
\text { (organic Rankine cycle) } \\
\text { low-temperature thermal power } \\
\text { generating system }\end{array}$ & CN101761461 (A); CN101761461 (B) & $\begin{array}{l}\text { Jie Ji; Jing Li; } \\
\text { Gang Pei }\end{array}$ \\
\hline 2010-07-01 & $\begin{array}{l}\text { Rankine-Brayton Engine Powered Solar } \\
\text { Thermal Aircraft }\end{array}$ & US2010162702 (A1); US8132412 (B2) & Bennett Charles L \\
\hline $2009-12-30$ & $\begin{array}{l}\text { Inner thermal storage solar } \\
\text { low-temperature thermal power } \\
\text { generation system }\end{array}$ & CN101614196 (A); CN101614196 (B) & $\begin{array}{l}\text { Jie Ji; Jing Li; } \\
\text { Gang Pei }\end{array}$ \\
\hline $2009-12-23$ & $\begin{array}{l}\text { Solar-energy low-temperature thermal } \\
\text { power-generation and photovoltaic } \\
\text { power-generation combination system }\end{array}$ & CN101608606 (A); CN101608606 (B) & $\begin{array}{l}\text { Jing Li; Gang Pei; } \\
\text { Jie Ji }\end{array}$ \\
\hline
\end{tabular}




\section{Conclusions}

The Organic Rankine Cycle (ORC) is a power generation technology that provides a solution to utilize a low and medium heat source such as solar energy. Integrated with technologies such as parabolic troughs, dish, solar towers or linear Fresnel reflectors, the system can convert solar energy into electrical energy. In this paper, a patent landscape review of ORC system applications for solar energy has been presented. Based on current data, the patent publication outlook for 2018 is very promising; whilst the data is only up to July 2018, the recorded number of published patents has exceeded more than half the number of published patents from the previous year. The top three countries/organization publishing patents related to the topic are China, the United States and World Intellectual Property Organization, with approximately $79 \%$ of total 1100 published patents selected for review. China, the US, and the World Intellectual Property Organization contributed 402, 224 and 241 published patents, respectively. The highest number of patents in China relate to solar towers, with 217 patents, followed by linear Fresnel reflectors with 81 patents. The main conclusion of this study is that ORC has high potential to be used for electricity generation, especially for small-scale operations compared to other alternative technologies, as evident from the number of published patents. China and the US, have been at the forefront of this development effort. Lately, there has been a higher interest in the use of solar towers for ORC application, led by China. The implementation of this technology can speed up if China and the US can implement workable filed patents which other countries may follow.

Author Contributions: This work was initiated and wrote by T.M.I.M., H.S., A.E.P.A. F.K. and H.C.O. contributed to the conceptual approach and thoroughly revising the paper. A.H.S. and M.R.B. checked the language of manuscript.

Funding: This research is funded by the Centre for Advanced Modeling and Geospatial Information Systems (CAMGIS), UTS under Grants 321740.2232397 and AAIBE Chair of Renewable Energy grant no: 201801 KETTHA.

Conflicts of Interest: The authors declare no conflict of interest.

\section{References}

1. Anderson, T.R.; Hawkins, E.; Jones, P.D. $\mathrm{CO}_{2}$, the greenhouse effect and global warming: From the pioneering work of Arrhenius and Callendar to today's Earth System Models. Endeavour 2016, 40, 178-187. [CrossRef]

2. Mahlia, T.M.I. Emissions from electricity generation in Malaysia. Renew. Energy 2002, 27, 293-300. [CrossRef]

3. Norhasyima, R.S.; Mahlia, T.M.I. Advances in $\mathrm{CO}_{2}$ utilization technology: A patent landscape review. J. $\mathrm{CO}_{2}$ Util. 2018, 26, 323-335. [CrossRef]

4. Masjuki, H.H.; Mahlia, T.M.I.; Choudhury, I.A.; Saidur, R. Potential $\mathrm{CO}_{2}$ reduction by fuel substitution to generate electricity in Malaysia. Energy Convers. Manag. 2002, 43, 763-770. [CrossRef]

5. Mahlia, T.M.I.; Lim, J.Y.; Aditya, L.; Riayatsyah, T.M.I.; Abas, A.P. Nasruddin, Methodology for implementing power plant efficiency standards for power generation: Potential emission reduction. Clean Technol. Environ. Policy 2018, 20, 309-327. [CrossRef]

6. Bel, G.; Joseph, S. Climate change mitigation and the role of technological change: Impact on selected headline targets of Europe's 2020 climate and energy package. Renew. Sustain. Energy Rev. 2018, 82, 3798-3807. [CrossRef]

7. Davy, R.; Gnatiuk, N.; Pettersson, L.; Bobylev, L. Climate change impacts on wind energy potential in the European domain with a focus on the Black Sea. Renew. Sustain. Energy Rev. 2018, 81, 1652-1659. [CrossRef]

8. do Nascimento Nadruz, V.; Lucia Casteli Figueiredo Gallardo, A.; Montaño, M.; Ramos, H.R.; Ruiz, M.S. Identifying the missing link between climate change policies and sectoral/regional planning supported by Strategic Environmental Assessment in emergent economies: Lessons from Brazil. Renew. Sustain. Energy Rev. 2018, 88, 46-53. [CrossRef]

9. Wang, B.; Wang, Q.; Wei, Y.M.; Li, Z.P. Role of renewable energy in China's energy security and climate change mitigation: An index decomposition analysis. Renew. Sustain. Energy Rev. 2018, 90, 187-194. [CrossRef]

10. Wang, D.D.; Sueyoshi, T. Climate change mitigation targets set by global firms: Overview and implications for renewable energy. Renew. Sustain. Energy Rev. 2018, 94, 386-398. [CrossRef] 
11. Wang, L.; Huang, G.; Wang, X.; Zhu, H. Risk-based electric power system planning for climate change mitigation through multi-stage joint-probabilistic left-hand-side chance-constrained fractional programming: A Canadian case study. Renew. Sustain. Energy Rev. 2018, 82, 1056-1067. [CrossRef]

12. Abas, P.E.; Mahlia, T. Techno-Economic and Sensitivity Analysis of Rainwater Harvesting System as Alternative Water Source. Sustainability 2019, 11, 2365. [CrossRef]

13. Demirbas, A. Progress and recent trends in biodiesel fuels. Energy Convers. Manag. 2009, 50, 14-34. [CrossRef]

14. Demirbas, A.D.M.F. Algae Energy: Algae as a New Source of Biodiesel; Springer: Berlin/Heidelberg, Germany, 2010.

15. Ding, L.; Yoshikawa, K.; Fukuhara, M.; Kowata, Y.; Nakamura, S.; Xin, D.; Muhan, L. Development of an ultra-small biomass gasification and power generation system: Part 2. Gasification characteristics of carbonized pellets/briquettes in a pilot-scale updraft fixed bed gasifier. Fuel 2018, 220, 210-219. [CrossRef]

16. Ghaffarpour, Z.; Mahmoudi, M.; Mosaffa, A.H.; Garousi Farshi, L. Thermoeconomic assessment of a novel integrated biomass based power generation system including gas turbine cycle, solid oxide fuel cell and Rankine cycle. Energy Convers. Manag. 2018, 161, 1-12. [CrossRef]

17. Lan, W.; Chen, G.; Zhu, X.; Wang, X.; Liu, C.; Xu, B. Biomass gasification-gas turbine combustion for power generation system model based on ASPEN PLUS. Sci. Total Environ. 2018, 628, 1278-1286. [CrossRef]

18. Hamzah, N.; Tokimatsu, K.; Yoshikawa, K. Prospective for Power Generation of Solid Fuel from Hydrothermal Treatment of Biomass and Waste in Malaysia; Energy Procedia; Elsevier: Amsterdam, The Netherlands, 2017; Volume 142, pp. 369-373.

19. Sajdak, M. Development and validation of new methods for identification of bio-char as an alternative solid bio-fuel for power generation. Fuel Process. Technol. 2017, 167, 229-240. [CrossRef]

20. Ahmed, A.; Abu Bakar, M.S.; Azad, A.K.; Sukri, R.S.; Mahlia, T.M.I. Potential thermochemical conversion of bioenergy from Acacia species in Brunei Darussalam: A review. Renew. Sustain. Energy Rev. 2018, 82, 3060-3076. [CrossRef]

21. Mehrali, M.; Latibari, S.T.; Mehrali, M.; Mahlia, T.M.I.; Metselaar, H.S.C.; Naghavi, M.S.; Sadeghinezhad, E.; Akhiani, A.R. Preparation and characterization of palmitic acid/graphene nanoplatelets composite with remarkable thermal conductivity as a novel shape-stabilized phase change material. Appl. Therm. Eng. 2013, 61, 633-640. [CrossRef]

22. Mardoyan, A.; Braun, P. Analysis of Czech subsidies for solid biofuels. Int. J. Green Energy 2015, 12, 405-408. [CrossRef]

23. Aditiya, H.B.; Chong, W.T.; Mahlia, T.M.I.; Sebayang, A.H.; Berawi, M.A.; Nur, H. Second generation bioethanol potential from selected Malaysia's biodiversity biomasses: A review. Waste Manag. 2016, 47, 46-61. [CrossRef]

24. Aditiya, H.B.; Mahlia, T.M.I.; Chong, W.T.; Nur, H.; Sebayang, A.H. Second generation bioethanol production: A critical review. Renew. Sustain. Energy Rev. 2016, 66, 631-653. [CrossRef]

25. Dharma, S.; Masjuki,H.H.; Ong, H.C.; Sebayang, A.H.; Silitonga, A.S.; Kusumo, F.; Mahlia, T.M.I. Optimization of biodiesel production process for mixed Jatropha curcas-Ceiba pentandra biodiesel using response surface methodology. Energy Convers. Manag. 2016, 115, 178-190. [CrossRef]

26. Kusumo, F.; Silitonga, A.S.; Masjuki, H.H.; Ong, H.C.; Siswantoro, J.; Mahlia, T.M.I. Optimization of transesterification process for Ceiba pentandra oil: A comparative study between kernel-based extreme learning machine and artificial neural networks. Energy 2017, 134, 24-34. [CrossRef]

27. Silitonga, A.S.; Atabani, A.E.; Mahlia, T.M.I.; Masjuki, H.H.; Badruddin, I.A.; Mekhilef, S. A review on prospect of Jatropha curcas for biodiesel in Indonesia. Renew. Sustain. Energy Rev. 2011, 15, 3733-3756. [CrossRef]

28. Manzano-Agugliaro, F.; Taher, M.; Zapata-Sierra, A.; Juaidi, A.; Montoya, F.G. An overview of research and energy evolution for small hydropower in Europe. Renew. Sustain. Energy Rev. 2017, 75, 476-489. [CrossRef]

29. Ak, M.; Kentel, E.; Savasaneril, S. Operating policies for energy generation and revenue management in single-reservoir hydropower systems. Renew. Sustain. Energy Rev. 2017, 78, 1253-1261. [CrossRef]

30. Lopes, V.S.; Borges, C.L.T. Impact of the Combined Integration of Wind Generation and Small Hydropower Plants on the System Reliability. IEEE Trans. Sustain. Energy 2015, 6, 1169-1177. [CrossRef]

31. Nakamura, Y.; Komatsu, H.; Shiratori, S.; Shima, R.; Saito, S.; Miyagawa, K. Development of high-efficiency and low-cost shroudless turbine for small hydropower generation plant. In Proceedings of the ICOPE 2015-International Conference on Power Engineering, Yokohama, Japan, 30 November-4 December 2015.

32. Zerrahn, A. Wind Power and Externalities. Ecol. Econ. 2017, 141, 245-260. [CrossRef] 
33. Chong, W.T.; Naghavi, M.S.; Poh, S.C.; Mahlia, T.M.I.; Pan, K.C. Techno-economic analysis of a wind-solar hybrid renewable energy system with rainwater collection feature for urban high-rise application. Appl. Energy 2011, 88, 4067-4077. [CrossRef]

34. Rocha, L.C.S.; Aquila, G.; Rotela Junior, P.; Paiva, A.P.D.; Pamplona, E.D.O.; Balestrassi, P.P. A stochastic economic viability analysis of residential wind power generation in Brazil. Renew. Sustain. Energy Rev. 2018, 90, 412-419. [CrossRef]

35. Sarfati, M.; Hesamzadeh, M.R.; Biggar, D.R.; Baldick, R. Probabilistic pricing of ramp service in power systems with wind and solar generation. Renew. Sustain. Energy Rev. 2018, 90, 851-862. [CrossRef]

36. Cao, L.; Qian, Z.; Zareipour, H.; Wood, D.; Mollasalehi, E.; Tian, S.; Pei, Y. Prediction of Remaining Useful Life of Wind Turbine Bearings under Non-Stationary Operating Conditions. Energies 2018, 11, 3318. [CrossRef]

37. Pioro, I.; Duffey, R. Nuclear Power as a Basis for Future Electricity Generation. J. Nucl. Eng. Radiat. Sci. 2015, 1, 011001. [CrossRef]

38. Koyama, K. Nuclear power generation. Yosetsu Gakkai Shi/J. Jpn. Weld. Soc. 2014, 83, 23-28. [CrossRef]

39. Pioro, I. Nuclear power as a basis for future electrical-energy generation in the world. In Proceedings of the International Congress on Advances in Nuclear Power Plants, ICAPP 2014, Charlotte, NC, USA, 6-9 April 2014; pp. 2387-2400.

40. Karim, R.; Karim, M.; Muhammad-Sukki, F.; Abu-Bakar, S.; Bani, N.; Munir, A.; Kabir, A.; Ardila-Rey, J.; Mas'ud, A. Nuclear Energy Development in Bangladesh: A Study of Opportunities and Challenges. Energies 2018, 11, 1672. [CrossRef]

41. Janjai, S. A method for estimating direct normal solar irradiation from satellite data for a tropical environment. Sol. Energy 2010, 84, 1685-1695. [CrossRef]

42. Ismail, M.S.; Moghavvemi, M.; Mahlia, T.M.I. Genetic algorithm based optimization on modeling and design of hybrid renewable energy systems. Energy Convers. Manag. 2014, 85, 120-130. [CrossRef]

43. Ismail, M.S.; Moghavvemi, M.; Mahlia, T.M.I. Design of an optimized photovoltaic and microturbine hybrid power system for a remote small community: Case study of Palestine. Energy Convers. Manag. 2013, 75, $271-281$. [CrossRef]

44. Ismail, M.S.; Moghavvemi, M.; Mahlia, T.M.I. Analysis and evaluation of various aspects of solar radiation in the Palestinian territories. Energy Convers. Manag. 2013, 73, 57-68. [CrossRef]

45. Aditya, L.; Mahlia, T.M.I.; Rismanchi, B.; Ng, H.M.; Hasan, M.H.; Metselaar, H.S.C.; Muraza, O.; Aditiya, H.B. A review on insulation materials for energy conservation in buildings. Renew. Sustain. Energy Rev. 2017, 73, $1352-1365$. [CrossRef]

46. Amin, M.; Putra, N.; Kosasih, E.A.; Prawiro, E.; Luanto, R.A.; Mahlia, T.M.I. Thermal properties of beeswax/graphene phase change material as energy storage for building applications. Appl. Therm. Eng. 2017, 112, 273-280. [CrossRef]

47. Korobitsyn, M.A. New and Advanced Energy Conversion Technologies: Analysis of Cogeneration, Combined and Integrated Cycles; University of Twente: Enschede, The Netherlands, 1998.

48. Prasetyo, P. Studi Penentuan Geometri Turbin Radial Aliran Masuk pada Siklus Rankine Organik Dengan Fluida Kerja R134a; Bandung Institute of Technology: Bandung, Indonesia, 2015.

49. Bellos, E.; Tzivanidis, C. Investigation of a hybrid ORC driven by waste heat and solar energy. Energy Convers. Manag. 2018, 156, 427-439. [CrossRef]

50. Dumont, O.; Dickes, R.; De Rosa, M.; Douglas, R.; Lemort, V. Technical and economic optimization of subcritical, wet expansion and transcritical Organic Rankine Cycle (ORC) systems coupled with a biogas power plant. Energy Convers. Manag. 2018, 157, 294-306. [CrossRef]

51. Sadreddini, A.; Fani, M.; Ashjari Aghdam, M.; Mohammadi, A. Exergy analysis and optimization of a CCHP system composed of compressed air energy storage system and ORC cycle. Energy Convers. Manag. 2018, 157, 111-122. [CrossRef]

52. Saloux, E.; Sorin, M.; Nesreddine, H.; Teyssedou, A. Reconstruction procedure of the thermodynamic cycle of organic Rankine cycles (ORC) and selection of the most appropriate working fluid. Appl. Therm. Eng. 2018, 129, 628-635. [CrossRef]

53. Vera, D.; Jurado, F.; Carpio, J.; Kamel, S. Biomass gasification coupled to an EFGT-ORC combined system to maximize the electrical energy generation: A case applied to the olive oil industry. Energy 2018, 144, 41-53. [CrossRef] 
54. Yari, M.; Ariyanfar, L.; Aghdam, E.A. Analysis and performance assessment of a novel ORC based multi-generation system for power, distilled water and heat. Renew. Energy 2018, 119, 262-281. [CrossRef]

55. Hanif, M.; Mahlia, T.M.I.; Aditiya, H.B.; Bakar, M.S.A. Energy and environmental assessments of bioethanol production from Sri Kanji 1 cassava in Malaysia. Biofuel Res. J. 2017, 4, 537-544. [CrossRef]

56. Hossain, N.; Zaini, J.H.; Mahlia, T.M.I. A review of bioethanol production from plant-based waste biomass by yeast fermentation. Int. J. Technol. 2017, 8, 5-18. [CrossRef]

57. Nasruddin; Idrus Alhamid, M.; Daud, Y.; Surachman, A.; Sugiyono, A.; Aditya, H.B.; Mahlia, T.M.I. Potential of geothermal energy for electricity generation in Indonesia: A review. Renew. Sustain. Energy Rev. 2016, 53, 733-740. [CrossRef]

58. Silitonga, A.S.; Masjuki, H.H.; Ong, H.C.; Yusaf, T.; Kusumo, F.; Mahlia, T.M.I. Synthesis and optimization of Hevea brasiliensis and Ricinus communis as feedstock for biodiesel production: A comparative study. Ind. Crops Prod. 2016, 85, 274-286. [CrossRef]

59. Mahlia, T.M.I. $\mathrm{CO}_{2}$ taxation on electricity generation for trees replanting in Malaysia. Energy Convers. Manag. 2003, 44, 723-730. [CrossRef]

60. Latibari, S.T.; Mehrali, M.; Mehrali, M.; Mahlia, T.M.I.; Metselaar, H.S.C. Synthesis, characterization and thermal properties of nanoencapsulated phase change materials via sol-gel method. Energy 2013, 61, 664-672. [CrossRef]

61. Eyidogan, M.; Canka Kilic, F.; Kaya, D.; Coban, V.; Cagman, S. Investigation of Organic Rankine Cycle (ORC) technologies in Turkey from the technical and economic point of view. Renew. Sustain. Energy Rev. 2016, 58, 885-895. [CrossRef]

62. Pereira, J.S.; Ribeiro, J.B.; Mendes, R.; Vaz, G.C.; André, J.C. ORC based micro-cogeneration systems for residential application-A state of the art review and current challenges. Renew. Sustain. Energy Rev. 2018, 92, 728-743. [CrossRef]

63. Quoilin, S.; Broek, M.V.D.; Declaye, S.; Dewallef, P.; Lemort, V. Techno-economic survey of organic rankine cycle (ORC) systems. Renew. Sustain. Energy Rev. 2013, 22, 168-186. [CrossRef]

64. Shi, L.; Shu, G.; Tian, H.; Deng, S. A review of modified Organic Rankine Cycles (ORCs) for internal combustion engine waste heat recovery (ICE-WHR). Renew. Sustain. Energy Rev. 2018, 92, 95-110. [CrossRef]

65. Tocci, L.; Pal, T.; Pesmazoglou, I.; Franchetti, B. Small scale Organic Rankine Cycle (ORC): A techno-economic review. Energies 2017, 10, 413. [CrossRef]

66. Burhan, M.; Jain, S.K. Tools for search, analysis and management of patent portfolios. DESIDOC J. Libr. Inf. Technol. 2012, 32, 204-213. [CrossRef]

67. Derwent Innovation. Available online: https:/www.derwentinnovation.com/login/ (accessed on 31 July 2018).

68. Moher, D.; Liberati, A.; Tetzlaff, J.; Altman, D.G. Preferred reporting items for systematic reviews and meta-analyses: The PRISMA statement. PLoS Med. 2009, 6, e1000097. [CrossRef] [PubMed]

69. Daily, S. Parabolic Trough Solar Collector Systems Made More Energy Efficient; Sandia National Laboratories: St. Louis, MI, USA, 2007.

70. Loni, R.; Kasaeian, A.B.; Askari Asli-Ardeh, E.; Ghobadian, B. Optimizing the efficiency of a solar receiver with tubular cylindrical cavity for a solar-powered organic Rankine cycle. Energy 2016, 112, 1259-1272. [CrossRef]

71. Patil, V.R.; Biradar, V.I.; Shreyas, R.; Garg, P.; Orosz, M.S.; Thirumalai, N.C. Techno-economic comparison of solar organic Rankine cycle (ORC) and photovoltaic (PV) systems with energy storage. Renew. Energy 2017, 113, 1250-1260. [CrossRef]

72. Cau, G.; Cocco, D. Comparison of Medium-size Concentrating Solar Power Plants based on Parabolic Trough and Linear Fresnel Collectors. Energy Procedia 2014, 45, 101-110. [CrossRef]

73. Serrano, M.I.R. Concentrating Solar Thermal Technologies. Available online: https://www.springer.com/gp/ book/9783319458823 (accessed on 30 April 2019).

74. Boyaghchi, F.A.; Sohbatloo, A. Assessment and optimization of a novel solar driven natural gas liquefaction based on cascade ORC integrated with linear Fresnel collectors. Energy Convers. Manag. 2018, 162, 77-89. [CrossRef]

75. Jing, L.; Gang, P.; Guangtao, G.; Xiao, R.; Ji, J. Solar Energy Overlapping Rankine Cycle Power Generation System with Different Exothermic Modes. Chinese Patent CN207064169 (U), 2 March 2018.

76. Yanping, Z.; Zhang, C.; Shuhong, H. Combined Solar Thermal Power Generation System. U.S. Patent Application 15/468,932, 8 March 2018. 
77. Zheng, M.; Kai, Z. Photovoltaic and Photo-Thermal Coupled Thermoelectric Generation System and method. Chinese Patent CN107061201 (A), 18 August 2018.

78. Rongji, X.; Meiyu, Y.; Yitao, L.; Shuhui, X.; Ruixiang, W.; Huasheng, W. Organic Rankine Cycle Power Generation Device and Flow Path Control Method for Heat Collecting Fluid. Chinese Patent CN106337788 (A); CN106337788 (B), 18 January 2017. 